\title{
Apoptosis as a Mechanism of Cell Death in Cultured T Lymphoblasts Acutely Infected with HIV-1
}

Chihiro Terai, ${ }^{\star *}$ Richard S. Kornbluth, ${ }^{\star}$ C. David Pauza, Douglas D. Richman, ${ }^{\star \|}$ and Dennis A. Carson ${ }^{\star *}$

*Departments of Medicine, "Pathology, and the ${ }^{\ddagger}$ Sam and Rose Stein Institute for Research on Aging, University of California

at San Diego, La Jolla, California 92093; and \$ Department of Pathology and Laboratory Medicine,

University of Wisconsin at Madison Medical School, Madison, Wisconsin 53706

\begin{abstract}
The mechanisms by which HIV-1 infection kills T lymphocytes are not clearly established. Apoptosis is an internally programmed cell death pathway that may regulate both $\mathrm{T}$ cell development and senescence, and that is characterized by cleavage of DNA at internucleosomal regions. The present experiments show that acute HIV-1 infection of MT2 lymphoblasts and activated normal peripheral blood mononuclear cells induces apoptosis. The addition of anti-gp1 20 neutralizing antibody, after HIV-1 infection of MT2 cells, permitted sustained high levels of viral replication, but blocked apoptosis and cell death. Apoptosis may account for the direct cytopathologic effects of HIV-1 in T cells. (J. Clin. Invest. 1991. 87:17101715.) Key words: AIDS • programmed cell death • MT2 cell • gp120 - DNA fragmentation
\end{abstract}

\section{Introduction}

Depletion of CD4 T lymphocytes is a central feature in the natural history of HIV-1 infection (1). In part, this depletion is due to a direct cytopathologic effect of HIV-1 toward CD4 lymphocytes (2). The mechanisms by which the virus can acutely kill these cells have not been precisely defined. Massive viral budding may result in cell death by destroying the cell membrane $(3,4)$. HIV-1 envelope glycoprotein on the surface of virions or infected cells can mediate cell fusion with either infected or uninfected cells bearing surface CD4 $(5,6)$. This syncytium formation is a cytopathologic event that can be lethal; however, it is not necessary for cell killing (7). Lethal parasitism of host cell transcriptional and translational machinery in the absence of cell fusion also has been invoked as a possible mechanism of cytocidal infection $(8,9)$.

$T$ lymphoblasts have an internally programmed cell death pathway, termed apoptosis, that results in the irreversible activation of $\mathrm{C} \mathrm{Ca}^{++}$-dependent endonuclease. Apoptosis has been thought to play a critical role in negative selection of self-reactive $T$ cells $(10,11)$, cell killing induced by cytotoxic $T$ lymphocytes (12), hormone-induced thymic atrophy $(13,14)$, lymphocyte death after IL-2 withdrawal (15), radiation-induced lymphocyte death (16), and cell death caused by drugs (17-19). A

Address correspondence to Dr. Dennis Carson, S-045, Department of Medicine, University of California at San Diego, La Jolla, CA 92093.

Received for publication 14 September 1990 and in revised form 31 December 1990

J. Clin. Invest.

(C) The American Society for Clinical Investigation, Inc.

0021-9738/91/05/1710/06 \$2.00

Volume 87, May 1991, 1710-1715 recent report demonstrated that the ligation of CD4 before signalling through the $T$ cell receptor (TCR) ${ }^{1}$ resulted in cell death by apoptosis (20). The HIV-1 gp 120 also binds to CD4, and has been reported to interfere with cell function (21-23). In view of the uncertainties concerning the basis for HIV-induced cytopathology, these experiments were conducted to determine whether or not HIV-1 infection induced apoptosis in T cells. Our results show that HIV-1 triggers endonuclease activation in established $\mathrm{T}$ lymphoblastoid cells and in activated peripheral blood $\mathrm{T}$ cells.

\section{Methods}

Infection of MT2 cells. MT2, T lymphoblastoid cells that are particularly sensitive to the cytotoxic consequences of HIV-1 infection (24), were propagated in complete medium (RPMI 1640 containing 100 $\mathrm{U} / \mathrm{ml}$ penicillin $\mathrm{G}, 100 \mu \mathrm{g} / \mathrm{ml}$ streptomycin, $2 \mathrm{mM} \mathrm{L}$-glutamine, and $10 \%$ fetal bovine serum [HyClone Laboratories, Logan, UT]).

A cell-free virus pool of the LAV-1 $1_{\text {BRU }}$ strain of HIV-1 (25) was prepared in CEM cells, and had a titer of $10^{8}$ tissue culture infective dose (TCID) so $_{0} / \mathrm{ml}$, assayed in MT2 cells. The HIV-1 was added to MT2 cells to yield a final multiplicity of infection (MOI) of $3 \mathrm{TCID}_{50} /$ cell, in complete medium containing $1 \mu \mathrm{g} / \mathrm{ml}$ polybrene. After $2 \mathrm{~h}$ at $37^{\circ}$ the cells were washed three times in RPMI 1640 medium and resuspended in replicate tube cultures to a final concentration of $10^{5} \mathrm{cells} / \mathrm{ml}$. This time point was designated $0 \mathrm{~h}$ after infection.

In some experiments, neutralizing murine monoclonal antibody 110.4 (26) was added to a final dilution of $1: 1,000$ of ascites $2 \mathrm{~h}$ after infection. A dilution of $1: 10^{5}$ inhibited plaque formation (27) by $50 \%$ and a dilution of $1: 10^{4}$ inhibited plaque formation or infectivity of MT2 cells by $>95 \%$. Pauza et al. (28) have demonstrated that the addition of this neutralizing anti-gp120 antibody, after infection of CEM cells has been achieved, inhibits the accumulation of viral DNA resulting from reinfection of the cells by progeny virus, and thereby inhibits cytopathology; however, it does not inhibit virus production as measured by $\mathrm{p} 24$ antigen, reverse transcriptase, or infectivity.

At $0,5,24,48$, and $72 \mathrm{~h}$ after infection, culture medium was harvested and centrifuged to remove cells for assay of HIV-1 p24 antigen. Cells were washed once in cold serum-free medium before analysis of cellular DNA composition, amount of viral DNA, cellular nucleotide pools (ATP, NAD, and deoxynucleotide triphosphates), and cell associated p24 antigen. Cell numbers and cell viabilities were determined with a hemocytometer by trypan blue exclusion. The number of syncytia were determined by counting 500 cells using a cytospin preparation.

These experimental conditions resulted in the expression of HIV-1 antigens on the surface of $70 \%$ of infected cells, either treated or not with neutralizing antibody after infection was established. This determination was made by fluorescence-activated cell sorting using a polyvalent human anti-HIV-1 serum that produced no signal with uninfected cells (data not shown).

1. Abbreviations used in this paper: MOI, multiplicity of infection; TCR, $\mathrm{T}$ cell receptor. 
Infection of activated peripheral blood lymphocytes. PBMC from the venous bloods of normal volunteers were separated by centrifugation using Ficoll-Hypaque (Sigma Chemical Co., St. Louis, MO), and stimulated with $3 \mu \mathrm{g} / \mathrm{ml}$ PHA in complete medium. At $2 \mathrm{~d}$, proliferating T cells were infected with HIV-1 at an MOI of 3 or 10 , as described above, and suspended in complete medium supplemented with $8 \mathrm{U} / \mathrm{ml}$ recombinant IL-2 (Dupont NEN Research Products, Westwood, MA). At 2 and $5 \mathrm{~d}$ after infection, cells were harvested for analysis.

DNA extraction and electrophoresis. Cells were lysed in $5 \mathrm{mM}$ Tris$\mathrm{HCl}$ (pH 7.4) containing $0.5 \%$ Triton $\mathrm{X}-100$ and $5 \mathrm{mM}$ EDTA on ice for $20 \mathrm{~min}$, and were centrifuged at $4,500 \mathrm{~g}$ for $20 \mathrm{~min}$ at $4^{\circ} \mathrm{C}$ to separate high molecular weight chromatin from the nucleosomal DNA fragments. The supernatant was removed and the pellet was dissolved in $5 \mathrm{mM}$ Tris- $\mathrm{HCl}$ containing $1 \%$ SDS and $5 \mathrm{mM}$ EDTA. The DNA content in the supernatant and pellet DNA fractions was quantitated by the diphenylamine assay, to determine the percentage of total fragmented DNA (29). After incubation with RNase $(50 \mu \mathrm{g} / \mathrm{ml}, 2 \mathrm{~h})$ and proteinase $\mathrm{K}(50 \mu \mathrm{g} / \mathrm{ml}, 16 \mathrm{~h})$, DNA was extracted with phenol/chloroform/isoamyl alcohol (25:24:1) and precipitated with $0.3 \mathrm{M}$ sodium acetate in ethanol, dried, and resuspended in electrophoresis buffer $(10$ $\mathrm{mM}$ Tris-HCl pH 8.0, 1 mM EDTA). The supernatant DNA derived from $2 \times 10^{6}$ cells was separated by electrophoresis on $2.0 \%$ agarose gels containing $0.5 \mu \mathrm{g} / \mathrm{ml}$ ethidium bromide at $50 \mathrm{~V}$ for $2 \mathrm{~h}$. A Haell digest of $\phi \times 174$ phage provided molecular weight standards. In one experiment, supernatant DNA was transferred from agarose gel to nitrocellulose paper and probed with radiolabelled pARV-2 cDNA, which contains almost all of the HIV-1 genome (30).

Measurement of nucleotide pool sizes. For measurements of intracellular deoxynucleotides, ATP, and NAD, cells were extracted with $60 \%$ methanol followed by $0.5 \mathrm{~N}$ perchloric acid (31). Recovery of an added internal dATP standard by this extraction method was $\geq 85 \%$. Deoxynucleoside 5 -triphosphate pools were quantitated by the DNA polymerase assay (32). ATP was quantitated after separation by ion exchange HPLC (33). NAD levels were measured by an enzymatic cycling assay (34). All reported results were repeated at least twice.

HIV-1 p24 antigen. HIV-1 p24 antigen determinations were performed by ELISA according to the manufacturer's instructions (Abbott Laboratories, North Chicago, IL).

$H I V-1$ RNA. For each time point, RNA was extracted from $10^{5}$ cells and transferred to Zeta-probe nylon membranes (Bio-Rad Laboratories, Richmond, CA) by slot-blotting. Viral RNA was detected by hybridization with a ${ }^{32}$-labelled HIV-1 probe from the pARV-2 plasmid (30). After hybridization, washing, and autoradiography, individual slots were excised, placed in scintillation fluid, and the bound ${ }^{32} \mathrm{P}$ measured in a scintillation counter.

Statistical analysis. Comparison between two groups was made by two sample $t$ test.

\section{Results}

Oligonucleosome formation in infected MT2 lymphoblasts. When the DNA in supernatants after centrifugation was electrophoresed on a $2 \%$ agarose gel, uninfected MT2 cells showed only a low level background smear (Fig. 1 a). In contrast, a characteristic 180-200 bp nucleosomal ladder was detectable in DNA prepared from MT2 cells as early as $24 \mathrm{~h}$ after HIV-1 infection. Southern blotting with the pARV-2 probe revealed no proviral DNA in the DNA fragments. In the experiment shown in Fig. $1 b, 23 \%$ of the DNA was fragmented at $24 \mathrm{~h}$ after infection, and the fragmentation increased at 48-72 h. At $24 \mathrm{~h}$ after HIV-1 infection, $92 \%$ of the cells still excluded trypan blue. In another experiment, $35 \%$ of the DNA was fragmented at $24 \mathrm{~h}$, compared to $6.7 \%$ in the control, and there was $3 \%$ syncytium formation, with an average of 4.2 nuclei, yielding $11.5 \%$ of the cells involved in giant cell formation. These data
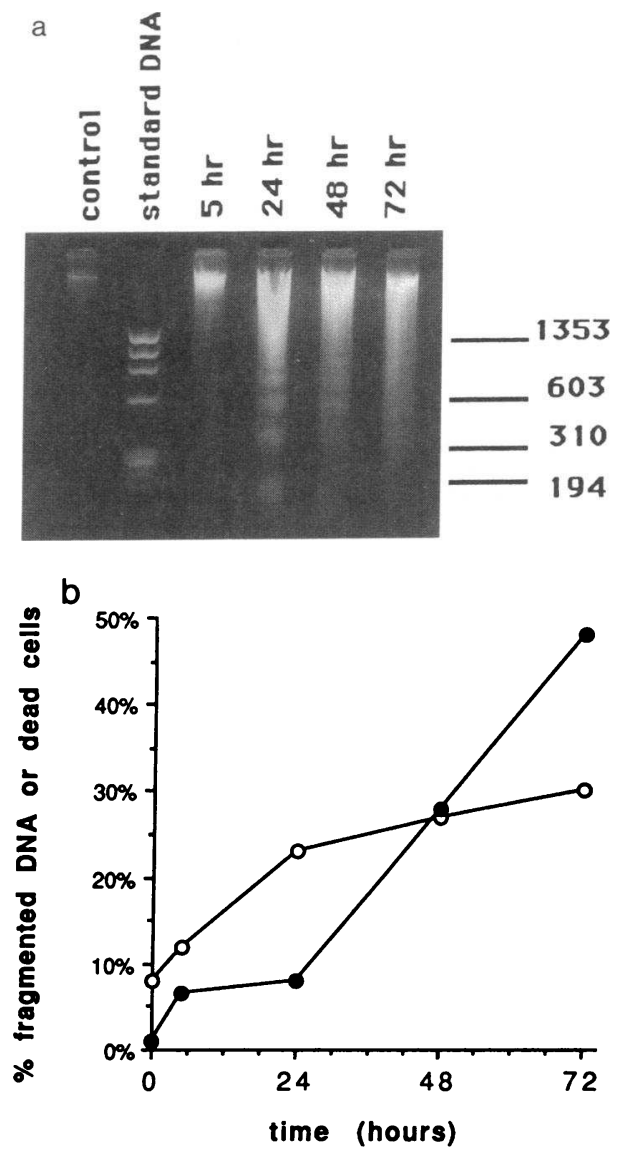

Figure 1. (a) DNA fragmentation in MT2 cells after HIV infection. Small-sized supernatant DNA after centrifugation was isolated from uninfected MT2 lymphoblasts (lane 1), or from cells exposed to HIV for 5 (lane 3), 24 (lane 4), 48 (lane 5), or 72 (lane 6) h. DNA from $2 \times 10^{6}$ cells per lane was separated on a $2 \%$ agarose gel. Lane 2 contains a standard HaeIII digest of fX174. Note the characteristic DNA ladder formation, consisting of multiples of 180-200 bp nucleosome fragments, that occurred in HIV infected cells as early as $24 \mathrm{~h}$ after infection. Similar data were obtained in four different experiments. (b) Percentage of fragmented DNA and viability of MT2 cells after HIV infection. The percentage of total DNA in the supernatant fraction and the percentage dead cells are shown. $-0-, \%$ fragmented DNA; - • - \% dead cells.

show that the DNA fragmentation was an earlier event than either syncytium formation or cell death.

Nucleotide pools. Deoxynucleotide pool changes have been reported to cause DNA fragmentation in human T lymphoblasts (18), by interference with DNA polymerization or ligation. Therefore, deoxynucleotide pools were quantitated in MT2 cells at daily intervals after HIV-1 infection. The results were normalized to the total DNA content of each sample, compared to uninfected cells, to correct for any effects of syncytium formation. As shown in Table $I$, the deoxynucleotide pools had increased by $6 \mathrm{~h}$ after HIV-1 exposure, and by $24 \mathrm{~h}$ after HIV-1 infection had risen two to fourfold. The greatest increase was in dCTP. The dCTP/dATP ratio changed from 0.69 in uninfected cells to 1.59 at $24 \mathrm{~h}$ after infection. At $48 \mathrm{~h}$ after HIV-1 infection, deoxynucleotide pools declined in association with reduced viability.

To determine whether the observed changes were specific 
Table I. Nucleotide Pool Changes in MT2 Cells after HIV Infection

\begin{tabular}{|c|c|c|c|c|c|c|}
\hline & dATP* & dTTP* & dCTP* & dGTP* & ATP* & $\mathrm{NAD}^{4}$ \\
\hline \multicolumn{7}{|c|}{ pmol/10 cells" } \\
\hline Uninfected MT2 & 6.1 & 14.0 & 4.2 & 2.0 & 3300 & 640 \\
\hline \multicolumn{7}{|l|}{ Infected MT2 } \\
\hline $6 \mathrm{~h}$ & 9.0 & 13.7 & 5.3 & 2.5 & 3710 & 770 \\
\hline $24 \mathrm{~h}$ & 11.5 & 23.4 & 18.3 & 4.9 & 3210 & 820 \\
\hline $48 \mathrm{~h}$ & 6.5 & 14.5 & 14.2 & 3.2 & 2750 & 630 \\
\hline
\end{tabular}

* Deoxynucleotide pools were determined by the DNA polymerase assay. ${ }^{*}$ ATP was quantitated by HPLC. ${ }^{8}$ NAD was measured by an enzymatic cycling assay. "Cell numbers at the indicated times after HIV infection were determined by the DNA content of each sample, compared to cells at the initiation of culture, to compensate for any possible effects of syncytium formation.

for deoxynucleotides, ATP and NAD levels were also measured at intervals after HIV-1 infection. ATP and NAD pools varied by only $10-20 \%$ at 6-24 h after HIV-1 infection, declining thereafter (Table I). Thus, the change in deoxynucleotide pools, in comparison to DNA content, was selective, and could not be attributed to cell fusion.

Effect of neutralizing antibody on viral production and cell death. The addition of anti-gp120 neutralizing antibody at $2 \mathrm{~h}$ after infection, improved cell viability and inhibited the induction of DNA fragmentation in HIV-infected MT2 cells measured at $72 \mathrm{~h}$ after infection (Fig. 2 and Table II). However, as shown in Tables III and IV, the levels of viral p24 antigen secreted into medium, the intracellular p24 antigen, and the quantity of viral RNA production, did not decrease in cells after incubation with neutralizing antibody. Rather, these parameters increased at $72 \mathrm{~h}$ compared to cells without antibody, probably due to improved cell survival. Thus, high levels of viral replication were sustained in antibody-treated infected cells, although the cytopathologic effect of the virus infection

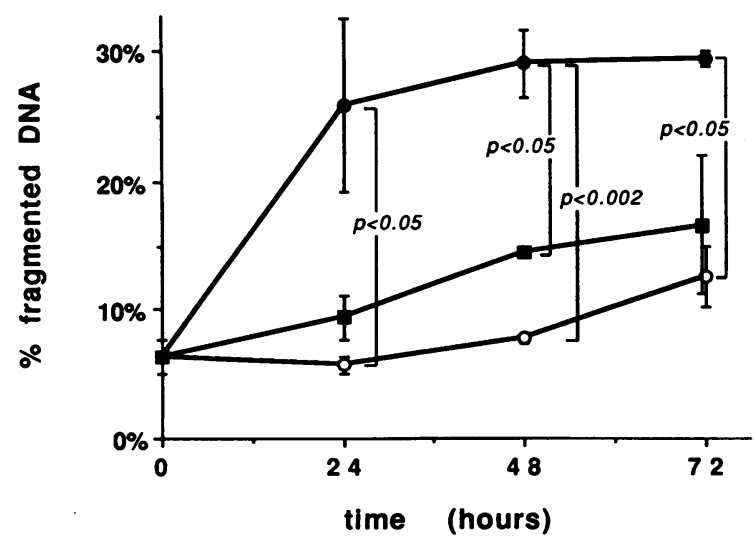

Figure 2. Inhibition of DNA fragmentation in HIV infected MT2 cells by anti-gp 120 neutralizing antibody. Monoclonal murine anti-gp 120 antibody 110.4 was added at $2 \mathrm{~h}$ after infection. The bars represent standard errors of the mean (control and neutralizing $\mathrm{Ab}(-), n=3$; neutralizing $\mathrm{Ab}(+), n=2) .-\mathrm{O}-$, control; $-\bullet-$, neutralizing $\mathrm{Ab}(-) ;--$, neutralizing $\mathrm{Ab}(+)$.
Table II. Cell Viability after HIV Infection with or without Neutralizing Antibody

\begin{tabular}{cccc}
\hline & \multicolumn{3}{c}{ Cell viability* } \\
\cline { 2 - 4 } $\begin{array}{c}\text { Time } \\
\text { after } \\
\text { infection }\end{array}$ & $\begin{array}{c}\text { Uninfected } \\
\text { MT2 }\end{array}$ & \multicolumn{2}{c}{ Infected MT2 } \\
\cline { 3 - 4 } & & Neut Ab $(-)$ & Neut Ab (+) \\
\hline$h$ & 98 & 98 & \\
0 & 94 & 76 & ND \\
24 & 93 & 56 & 91 \\
48 & 82 & 31 & 63 \\
72 & & & 63 \\
\hline
\end{tabular}

* Cell viability was determined by trypan blue exclusion. ${ }^{\ddagger}$ Neut $\mathrm{Ab}$, anti-gp120 neutralizing antibody.

and the endonucleolytic cleavage of host chromosomal DNA were blocked.

$H I V-1$ infection in activated peripheral blood lymphocytes. To ascertain the role of apoptosis in HIV-1 infection of normal $T$ lymphocytes, we determined whether or not DNA fragmentation occurred in activated PBMC infected with HIV-1. With the same viral inoculum $(\mathrm{MOI}=3$ ) used for infection of MT2 cells, PHA-stimulated PBMC were less sensitive to the cytopathologic effect of the LAV-1 $1_{\text {BRU }}$ strain of HIV-1, as shown by cell viabilities of $97 \%$ vs. $89 \%$ at $2 \mathrm{~d}$, and $97 \%$ vs. $86 \%$ at $5 \mathrm{~d}$, for control and HIV-1 infected lymphocytes, respectively. However, agarose gel electrophoresis showed a typical DNA ladder in HIV-infected PBMC, that reached a maximum at $5 \mathrm{~d}$ after infection; at that time the fragmented DNA was $18.2 \%$ compared to $5.5 \%$ in the control. When a higher viral inoculum $(\mathrm{MOI}=10)$ was employed, cell viability dropped to $69 \%$ (control $94 \%$ ) at $2 \mathrm{~d}$ and $67 \%$ (control $99 \%$ ) at $5 \mathrm{~d}$ after infection. The fragmented DNA of infected cells increased to $35.1 \%$ (control $6.7 \%$ ) at $2 \mathrm{~d}$ and $27.4 \%$ (control $7.3 \%$ ) at $5 \mathrm{~d}$, shown as a characteristic DNA ladder in agarose gel (Fig. 3). This confirmed that apoptosis occurred in HIV-infected normal human PBMC.

\section{Discussion}

Apoptosis is an active "suicide" process, in which an endogenous endonuclease cuts DNA in the nucleosomal linker re-

Table III. HIV p24 Antigen Production of Infected MT2

\begin{tabular}{|c|c|c|c|c|}
\hline \multirow{2}{*}{$\begin{array}{l}\text { Time } \\
\text { after } \\
\text { infection }\end{array}$} & \multicolumn{2}{|c|}{ p24 in medium * } & \multicolumn{2}{|c|}{ p24 in MT2 } \\
\hline & $\begin{array}{c}\text { Neut } \mathbf{A} \mathbf{b}^{6} \\
(-)\end{array}$ & $\begin{array}{c}\text { Neut Ab } \\
(+)\end{array}$ & $\begin{array}{c}\text { Neut Ab } \\
(-)\end{array}$ & $\begin{array}{c}\text { Neut } A b \\
(+)\end{array}$ \\
\hline$h$ & \multicolumn{2}{|c|}{$n g / m l$} & \multicolumn{2}{|c|}{$n g / 10^{4}$ cells } \\
\hline 0 & 1.34 & ND & 4.5 & ND \\
\hline 5 & 18.3 & 18.3 & 3.6 & 3.0 \\
\hline 24 & 26.9 & 26.1 & 3.6 & 3.0 \\
\hline 48 & 75.4 & 70.9 & 11.8 & 7.3 \\
\hline 72 & 328 & 834 & 12.5 & 47.5 \\
\hline
\end{tabular}

* HIV p24 antigen in cell free supernatant medium was measured by ELISA. ${ }^{\ddagger}$ HIV p24 antigen in washed cell pellets after centrifugation was measured. ${ }^{8}$ Neut Ab, anti-gp1 20 neutralizing antibody. 
Table IV. HIV RNA Production in Infected MT2 Cells

\begin{tabular}{cccc}
\hline & \multicolumn{3}{c}{ Viral RNA* production in } \\
\cline { 2 - 4 } $\begin{array}{c}\text { Time } \\
\text { after } \\
\text { infection }\end{array}$ & $\begin{array}{c}\text { Uninfected } \\
\text { MT2 }\end{array}$ & \multicolumn{2}{c}{ Infected MT2 } \\
\cline { 2 - 4 } & & Neut Ab A $^{*}(-)$ & Neut Ab (+) \\
\hline$h$ & 266 & 504 & \\
0 & ND & 353 & ND \\
5 & ND & 976 & 397 \\
24 & ND & 1701 & 707 \\
48 & ND & 3500 & 3946 \\
72 & & & 5674 \\
\hline
\end{tabular}

* RNA extracted from $10^{5}$ cells was determined by slot-blotting using ${ }^{32}$ P-labelled genomic probe. ${ }^{\ddagger}$ Neut $\mathrm{Ab}$, anti-gp120 neutralizing antibody.

gions while cells are still viable. A typical DNA nucleosomal ladder was seen in MT2 cells at $24 \mathrm{~h}$ after infection of HIV-1, and in peripheral blood lymphocytes after 2 and $5 \mathrm{~d}$. The viability of infected MT2 cells, judged by dye exclusion, was $92 \%$ at $24 \mathrm{~h}$ after infection. At this time, $23-35 \%$ of total DNA was found in the supernatant fraction after centrifugation, demon- strating that apoptosis occurred before the loss of cellular integrity. At later times after infection, cell death increased progressively, in conjunction with further DNA fragmentation.

The biochemical events that cause apoptosis vary among different cell types. In immature $\mathrm{T}$ lymphocytes, any stimulus that engenders a sustained rise in cytosolic free $\mathrm{Ca}^{++}$can activate a latent $\mathrm{Ca}^{++}$-dependent endonuclease $(11,14,35)$. In this regard, the rate of influx of $\mathrm{Ca}^{++}$into cells infected with HIV-1 was reported to increase to a level similar to that of uninfected cells treated with the $\mathrm{Ca}^{++}$ionophore $\mathrm{A} 23187$ (3), and purified gp120 has been shown to increase intracellular free $\mathrm{Ca}^{++}$in CD4 $\mathrm{T}$ cells (36) and in neuronal cells (37). However, $\mathrm{Ca}^{++}$ influx alone is probably not sufficient to cause apoptosis in MT2 cells, since the ionophore A23187 $(0.5-20 \mu \mathrm{M}, 24 \mathrm{~h})$ or ionomycin $(0.1-1 \mu \mathrm{M}, 24 \mathrm{~h})$ did not induce DNA fragmentation in MT2 cells (data not shown).

Major imbalances in the ratios of the four major deoxynucleotides can also lead to DNA fragmentation in T cells (18), by blocking DNA polymerization and ligation. We found that the levels of all four deoxynucleotides increased after HIV-1 infection, and the dCTP/dATP ratio inverted. These changes are consistent with a block in replicative DNA synthesis, and may have sensitized lymphocytes to the $\mathrm{Ca}^{++}$-activated endonuclease. A sudden cessation of DNA polymerization following HIV-1 infection could mimic growth factor deprivation (15),
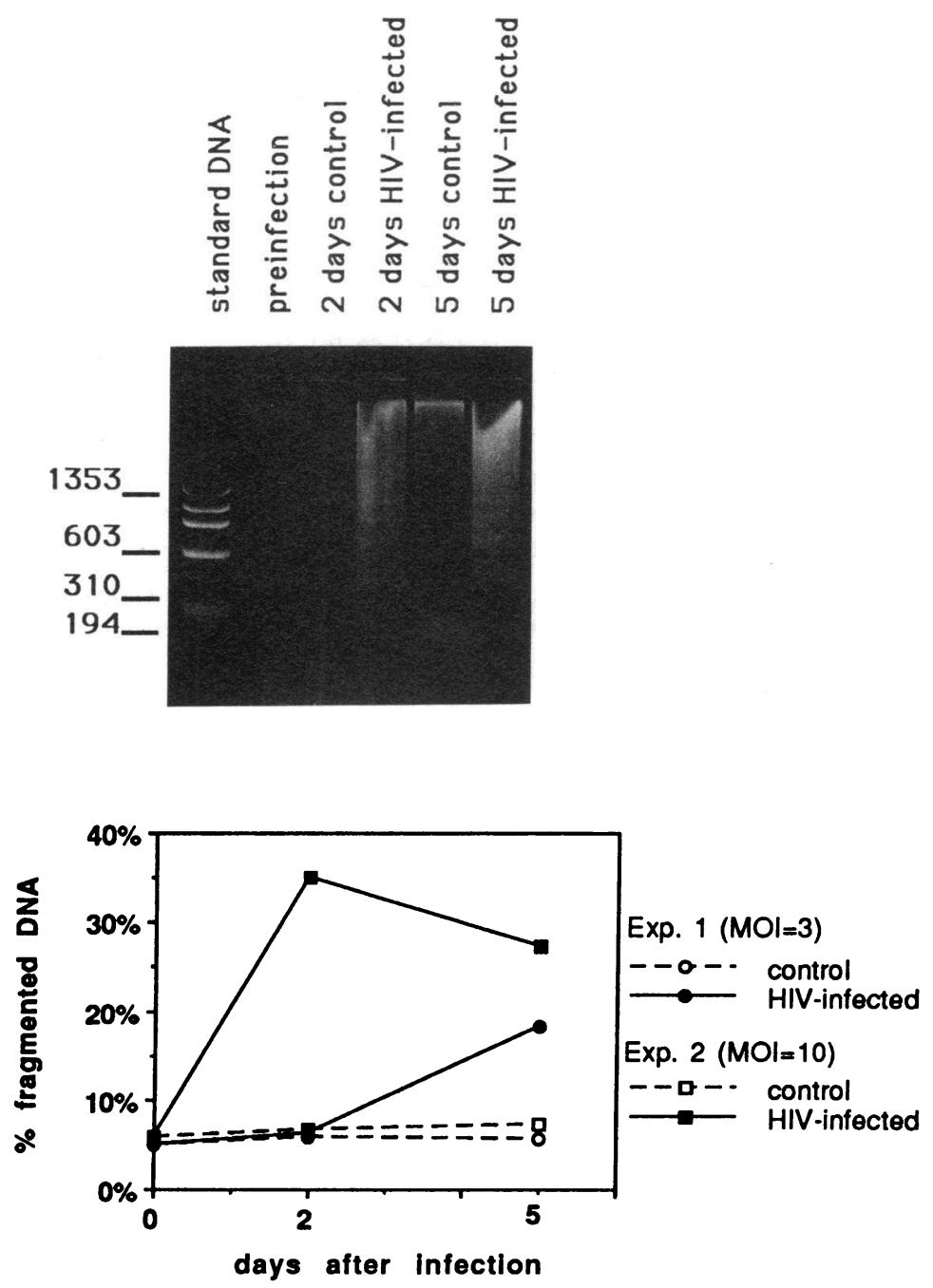

Figure 3. DNA fragmentation of activated PBMC infected with HIV. PBMC were stimulated with PHA for $2 \mathrm{~d}$, cultured in complete medium containing rIL-2, and infected with HIV. Gel electrophoresis of supernatant DNA of the experiment with a high infectious dose (MOI $=10$ ) was performed at 2 and $5 \mathrm{~d}$ after infection (top), and the percentage of fragmented DNA was measured by the diphenylamine assay (bottom). 
an established cause of apoptosis, and leave exposed internucleosomal regions of DNA accessible to endonuclease.

The massive parasitism of host cell transcriptional and translational machinery by replicating viruses may cause cytopathology $(8,9)$. However, this mechanism alone probably did not trigger apoptosis in HIV-infected lymphoblasts, since the process had already started in MT2 cells at $24 \mathrm{~h}$ after infection, when the cellular energy status was intact, and ATP and NAD pools were not depleted.

The anti-gp 120 neutralizing antibody 110.4 blocked DNA fragmentation and improved cell viability in infected MT2 cells; however, high levels of viral replication were sustained. As shown in Table III, p24 antigen secretion into the medium of infected MT2 cells with the antibody was similar to the control culture at $48 \mathrm{~h}$, and even higher thereafter. The destruction of the cell membrane that occurs as a result of massive viral budding may be a direct cytopathologic effect of HIV-1 $(3,4)$. However, in MT2 cells incubated with neutralizing antibody, virus budding appeared to continue without severe cytopathologic consequences. CD4 cells infected with HIV-1 may show decreased expression of CD4 surface antigen $(38,39)$, because of reduced levels of CD4-specific mRNA and the complexing of the protein with viral envelope proteins $(4,9)$. At $72 \mathrm{~h}$ after infection, MT2 cells treated with the antibody showed a several times higher intracellular p24 antigen level, compared to cells without the antibody, with cell viabilities of $63 \%$ vs. $31 \%$, respectively, even though neutralizing antibody would not be expected to block intracellular complexing of CD4 molecules with viral envelope proteins. Neutralizing antibody to gp120 blocked syncytium formation of infected cells, as well as DNA fragmentation. However, at $24 \mathrm{~h}$ after infection, the percentage of cells involved in syncytium formation (11.5\%) was too small to account the DNA fragmentation (35.1\%). Collectively, the evidence suggests that neither the intracellular complexing of CD4 with the HIV-1 envelope, massive viral budding, nor syncytium formation, is likely to be necessary for the induction of apoptosis in HIV-1 infection.

HIV-1 infection results in not only quantitative but also qualitative defects in CD4 T cell function. Recent studies of T cell activation have revealed a signal transduction pathway, involving CD4, that is independent from the CD3-TCR complex (40). Perturbation of the CD4 molecule was reported to inhibit proliferation induced by anti-CD3 antibodies (41). When preceded by ligation of CD4, signalling through TCR resulted in $T$ cell unresponsiveness due to the induction of apoptosis (20). These results imply that CD4 is critically involved in determining the outcome of signals generated through the TCR.

In part, the process of apoptosis in lymphocytes may be related to abortive cell activation (42). Soluble gp1 20 alone has been reported to suppress $T$ cell activation $(22,23)$, and recent data indicate that the binding of gp120 and gp160 to CD4 inhibits CD3-TCR signal transduction pathway (43). The activation of protein kinase $C$, induced by second signals delivered by accessory cells during $T$ cell activation, does not occur during apoptosis (42). Indeed, addition of tetradecanoylphorbol13-acetate, a direct stimulator of PKC, prevents apoptosis in lymphocytes (11), and also inhibits HIV-1 cytopathology (4).

Neutralizing antibody 110.4 prevents reinfection and syncytium formation, but does not interfere with gp 120 mediated binding of HIV-1 to CD4 receptors $(26,28)$. However, because the binding of HIV-1 to CD4 is a separate step from virus infection and fusion $(26,28,44,45)$, the monoclonal antibody must have inhibited an event subsequent to viral attachment. Cell death after HIV-1 superinfection may have been fostered by the accumulation of unintegrated viral DNA (28), active viral protease, or cell proteins induced by viral transactivation. These consequences of HIV infection, together with the effects of HIV-1 induced $\mathrm{Ca}^{++}$increase, imbalances in deoxynucleotide pools necessary for faithful DNA repair, a sudden cessation of DNA polymerization, and negative signals elicited by the binding of HIV-1 gp 120 to CD4, may have provided ample stimuli for lethal endonuclease activation in HIV-1 infected T lymphoblasts. The mechanism by which HIV-1 induces apoptosis, and its role in the progressive immunodeficiency of HIV1 infection, remain important areas for future investigation.

\section{Acknowledgments}

This work was supported in part by grants GM-23200, TW-00011, HB-67019, AI-52572, AI-24591, and AI-25316 from the National Institutes of Health, by the Research Center for AIDS of the San Diego Veterans Affairs Medical Center, and by funds provided by the State of California and allocated on the recommendation of the Universitywide Task Force on AIDS, and by a grant from the Council for Tobacco Research.

\section{References}

1. Fauci, A. S. 1988. The human immunodeficiency virus: infectivity and mechanisms of pathogenesis. Science (Wash. DC). 239:617-622.

2. Popovic, M., M. G. Sarngadharan, E. Read, and R. C. Gallo. 1984. Detection, isolation, and continuous production of cytopathic retroviruses (HTLV-III) from patients with AIDS and pre-AIDS. Science (Wash. DC). 224:497-500.

3. Lynn, W. S., A. Tweedale, and M. W. Cloyd. 1988. Human immunodeficiency virus (HIV-1) cytotoxicity: perturbation of the cell membrane and depression of phospholipid synthesis. Virology. 163:43-51.

4. Leonard, R., D. Zagury, I. Desportes, J. Bernard, J-F. Zagury, and R. C. Gallo. 1988. Cytopathic effect of human immunodeficiency virus in T4 cells is linked to the last stage of virus infection. Proc. Natl. Acad. Sci. USA. 85:3570 3574.

5. Lifson, J. D., G. R. Reyes, M. S. McGrath, B. S. Stein, and E. G. Engleman. 1986. AIDS retrovirus induced cytopathology: giant cell formation and involvement of CD4 antigen. Nature (Lond.). 232:1123-1127.

6. Sodroski, J., W. C. Goh, C. Rosen, K. Campbell, and W. A. Haseltine. 1986. Role of the HTLV-III/LAV envelope in syncytium formation and cytopathicity. Nature (Lond.). 322:470-474.

7. Somasundaran, M., and H. Robinson. 1987. A major mechanism of human immunodeficiency virus-induced cell killing does not involve cell fusion. $J$. Virol. 61:3114-3119.

8. Shaw, G. M., B. H. Hahn, S. K. Arya, J. E. Groopman, R. C. Gallo, and F. Wong-Staal. 1984. Molecular characterization of human T-cell leukemia (lymphotropic) virus type III in the acquired immune deficiency syndrome. Science (Wash. DC). 226:1165-1171.

9. Somasundaran, M., and H. L. Robinson. 1988. Unexpectedly high levels of HIV-1 RNA and protein synthesis in a cytocidal infection. Science (Wash. DC). 242:1554-1557.

10. Smith, C. A., G. T. Williams, R. Kingston, E. J. Jenkinson, and J. J. T. Owen. 1989. Antibodies to CD3/T-cell receptor complex induce death by apoptosis in immature T cells in thymic cultures. Nature (Lond.). 337:181-184.

11. McConkey, D. J., P. Hartzell, J. F. Amador-Perez, S. Orrenius, and M. Jondal. 1989. Calcium-dependent killing of immature thymocytes by stimulation via the CD3/T cell receptor complex. J. Immunol. 143:1801-1806.

12. Russell, J. H., V. R. Masakowski, and C. B. Dobos. 1980. Mechanism of immune lysis. I. Physiological distinction between target cell death mediated by cytotoxic T lymphocytes and antibody plus complement. J. Immunol. 124:1 1001105.

13. Wyllie, A. H. 1980. Glucocorticoid-induced thymocyte apoptosis is associated with endogenous endonuclease activation. Nature (Lond.). 284:555-556.

14. Cohen, J. J., and R. C. Duke. 1984. Glucocorticoid activation of a calcium-dependent endonuclease in thymocyte nuclei leads to cell death. $\mathrm{J}$. Immunol. 132:38-42.

15. Duke, R. C., and J. J. Cohen. 1986. IL-2 addiction: withdrawal of growth factor activates a suicide program in dependent T cells. Lymphokine Res. 5:289299. 
16. Sellins, K. S., and J. J. Cohen. 1987 . Gene induction by $\gamma$-irradiation leads to DNA fragmentation in lymphocytes. J. Immunol. 139:3199-3206.

17. Wyllie, A. H., R. G. Morris, A. L. Smith, and D. Dunlop. 1984. Chromatin cleavage in apoptosis: association with condensed chromatin morphology and dependence on macromolecular synthesis. J. Pathol. 142:67-77.

18. Kizaki, H., H. Shimada, F. Ohsaka, and T. Sakurada. 1988. Adenosine, deoxyadenosine, and deoxyguanosine induce DNA cleavage in mouse thymocytes. J. Immunol. 141:1652-1657.

19. McConkey, D. J., P. Hartzell, S. K. Duddy, H. Hakansson, and S. Orrenius. 1988. 2,3,7,8-tetrachlorodibenzo-p-dioxin kills immature thymocytes by $\mathrm{Ca}^{++}$-mediated endonuclease activation. Science (Wash. DC). 242:256-259.

20. Newell, M. K., L. J. Haughn, C. R. Maroun, and M. H. Julius. 1990 Death of mature $\mathrm{T}$ cells by separate ligation of CD4 and the T-cell receptor for antigen. Nature (Lond.). 347:286-289.

21. Hoxie, J. A., J. D. Alpers, J. L. Rackowski, K. Huebner, B. S. Haggarty, A. J. Cedarbaum, and J. C. Reed. 1986. Alterations in T4 (CD4) protein and mRNA synthesis in cells infected with HIV. Science (Wash. DC). 234:11231127.

22. Gurley, R. J., K. Ikeuchi, R. A. Byrn, K. Anderson, and J. E. Groopman. 1989. $\mathrm{CD}^{+}$lymphocyte function with early human immunodeficiency virus infection. Proc. Natl. Acad. Sci. USA. 86:1993-1997.

23. Diamond, D. C., B. P. Sleckman, T. Gregory, L. A. Lasky, J. L. Greenstein, and S. J. Burakoff. 1988. Inhibition of $\mathrm{CD4}^{+} \mathrm{T}$ cell function by the HIV envelope protein, gp120. J. Immunol. 141:3715-3717.

24. Harada, S., Y. Koyanagi, and N. Yamamoto. 1985. Infection of HTLVIII/LAV in HTLV-I-carrying cells MT-2 and MT-4 and application in a plaque assay. Science (Wash. DC). 229:563-566.

25. Alizon, M., P. Sonigo, F. Barre-Sinoussi, J-C. Chermann, P. Tiollais, L. Montagnier, and S. Wain-Hobson. 1984. Molecular cloning of lymphadenopathy-associated virus. Nature (Lond.). 312:757-760.

26. Linsley, P. S., J. A. Ledbetter, E. Kinney-Thomas, and S-L. Hu. 1988 Effects of anti-gp 120 monoclonal antibodies on CD4 receptor binding by the env protein of human immunodeficiency virus type $1 . J$. Virol. 62:3695-3702.

27. Larder, B. A., G. Darby, and D. D. Richman. 1989. HIV with reduced sensitivity to Zidovudine (AZT) isolated during prolonged therapy. Science (Wash. DC) 243:1731-1734.

28. Pauza, C. D., J. E. Galindo, and D. D. Richman. 1990. Reinfection results in accumulation of unintegrated viral DNA in cytopathic and persistent human immunodeficiency virus type I infection of CEM cells. J. Exp. Med. 172:10351042.

29. Burton, K. 1956. A study of the conditions and mechanism of the diphenylamine reaction for the colorimetric estimation of deoxyribonucleic acid. Biochem. J. 62:315-323.

30. Richman, D. D., J. A. McCutchan, and S. A. Spector. 1987. Detecting human immunodeficiency virus RNA in peripheral blood mononuclear cells by nucleic acid hybridization. $J$. Infect. Dis. 156:823-827.

31. North, T. W., R. K. Bestwick, and C. K. Mathews. 1980. Detection of activities that interfere with the enzymatic assay of deoxyribonucleoside 5'-triphosphates. J. Biol. Chem. 255:6640-6645.

32. Skoog, L. 1970. An enzymatic method for the determination of dCTP and dGTP in picomole amounts. Eur. J. Biochem. 17:202-208.

33. Carson, D. A., D. B. Wasson, J. Kaye, B. Ullman, D. W. Martin, Jr., R. K. Robins, and J. A. Montgomery. 1980. Deoxycytidine kinase-mediated toxicity of deoxyadenosine analogs toward malignant human lymphoblasts in vitro and toward murine L1210 leukemia in vivo. Proc. Natl. Acad. Sci. USA. 77:68656869.

34. Jacobson, E. L., and M. K. Jacobson. 1976. Pyridine nucleotide levels as a function of growth in normal and transformed 3T3 cells. Arch. Biochem. Biophys. 175:627-634.

35. McConkey, D. J., P. Hartzell, P. Nicotera, and S. Orrenius. 1989. Calcium-activated DNA fragmentation kills immature thymocytes. FASEB (Fed. Am. Soc. Exp. Biol.) J. 3:1843-1849.

36. Kornfeld, H., W. W. Cruikshank, S. W. Pyle, J. S. Berman, and D. M. Center. 1988. Lymphocyte activation by HIV-1 envelope glycoprotein. Nature (Lond.). 335:445-448.

37. Dreyer, E. B., P. K. Kaiser, J. T. Offermann, and S. A. Lipton. 1990. HIV-1 coat protein neurotoxicity prevented by calcium channel antagonists. Science (Wash. DC). 248:364-367.

38. Dalgleish, A. G., P. C. Beverley, P. R. Clapham, D. H. Crawford, M. F. Greaves, and R. A. Weiss. 1984. The CD4 (T4) antigen is an essential component of the receptor for the AIDS retrovirus. Nature (Lond.). 312:763-767.

39. Klatzmann, D., E. Champagne, S. Chamaret, J. Gruest, D. Guetard, T. Hercend, J. Gluckman, and L. Montagnier. 1984. T-lymphocyte T4 molecule behaves as the receptor for human retrovirus LAV. Nature (Lond.). 312:767-768.

40. Veilette, A., M. A. Bookman, E. M. Horak, L. E. Samelson, and J. B. Bolen. 1989. Signal transduction through the CD4 receptor involves the activa-

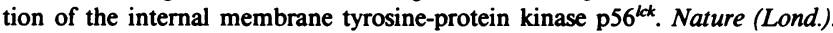
338:257-259.

41. Bank, I., and L. Chess. 1985. Perturbation of the T4 molecule transmits a negative signal to T cells. J. Exp. Med. 162:1294-1303.

42. McConkey, D. J., S. Orrenius, and M. Jondal. 1990. Cellular signalling in programmed cell death (apoptosis). Immunol. Today. 11:120-121.

43. Cefai, D., P. Debre, M. Kaczorek, T. Idziorek, B. Autran, and G. Bismuth 1990. Human immunodeficiency virus-1 glycoproteins gp 120 and gp 160 specifcally inhibit the $\mathrm{CD} 3 / \mathrm{T}$ cell-antigen receptor phosphoinositide transduction pathway. J. Clin. Invest. 86:2117-2124.

44. Healey, D., L. Dianda, J. P. Moore, J. S. McDougal, M. J. Moore, P. Estess, D. Buck, P. D. Kwong, P. C. L. Beverley, and Q. J. Sattentau. 1990. Novel anti-CD4 monoclonal antibodies separate human immunodeficiency vinus infection and fusion of $\mathrm{CD}^{+}$cells from virus binding. J. Exp. Med. 172:1233-1242.

45. Celada, F., C. Cambiaggi, J. Maccari, S. Burastero, T. Gregory, E. Patzer, J. Porter, C. McDanal, and T. Matthews. 1990. Antibody raised against soluble CD4-rgp 120 complex recognizes the CD4 moiety and blocks membrane fusion without inhibiting CD4-gp120 binding. J. Exp. Med. 172:1143-1150. 